\title{
Co z tym światem - czy musi mieć sens? Arcybiskup Józef Życiński i media
}

Prof. DR HAB. WIESŁAW GODZIC

SWPS Uniwersytet Humanistycznospołeczny

Pytanie: „Wymień nazwisko znanego żołnierza” Odpowiedź: „Nieznany żołnierz”

(Teleturniej Family Fortunes)

„Piętnaście lat zabrało mi odkrycie, że nie mam żadnego talentu. Ale wtedy nie mogłem zrezygnować z kariery, bo byłem zbyt znany".

(R. Benchley, aktor i dziennikarz)

Felietonista religijny „Gazety Wyborczej” kilka dni przed piątą rocznicą śmierci abp. Józefa Życińskiego stwierdził, że powstała „wyrwa coraz trudniejsza do zasypania”. Dotyczy ona dwóch sfer (tym samym mogłaby służyć jako metafora tej sytuacji): aktualnej społeczno-politycznej sytuacji w kraju oraz porządkowania Kościoła pod przewodnictwem papieża Franciszka. Wyrw spowodowanych tą śmiercią jest więcej. Od banalnego „Będzie nam Ciebie brakowało!" - po wymowne milczenie. Biskup filozof zaprasza nas, żeby nie milczeć, a nawet wymaga, aby zająć 
się jego myślą zarówno w sensie teologicznym, jak i kulturoznawczym.

Trudno nie zgodzić się z sądami tych wszystkich, którzy zetknęli się z jego myślą i byli nią zafascynowani. Kwestie szczegółowe zostawiam innym: godniejszym, specjalistom, ale także zwykłym ludziom, których Życiński przyciągał bezpośredniością partnera i nie odstraszał powagą arcybiskupa. Część z tych wątków była już poruszana podczas konferencji: duchowość chrześcijańska i media, kategoria poetyckości w pismach Życińskiego.

Zastanawiam się nad typem refleksji kulturoznawczej, którą można by zastosować $\mathrm{w}$ tym przypadku i która w dodatku byłaby oryginalna. Wszak pod pojęciem „tekstu” powinniśmy rozumieć nie tylko dorobek - zapisany i dyskutowany. Trzeba wziąć także po uwagę rozległe konteksty, wśród których znajdziemy metody filozofowania i snucia refleksji, zakres tematyczny, metody dialogizowania/monologizowania. Niosą one ze sobą cechę - ogólnie rzecz biorąc - atrakcyjności i aktualności: są takie dzisiejsze, ale to nie są bańki mydlane, znikające zanim na nie spojrzysz. Trudno doszukać się w nich „księżego stylu” - rozumiem to jako cechę neutralną, bez potrzeby wartościowania jej. Przy tym nie sądzę, żeby chodziło o uwodzenie czytelnika fałszywymi obietnicami, ale o autentyczność myśli. Ich autor zdaje się mówić: nie twórzmy gett językowych, rządzących się rytuałem pustych słów. Mówmy prosto, tak prosto jak się da; nie ześlizgując się do obszaru prostactwa językowego. Jednocześnie zachowajmy cechy 
idiolektu językowego - takie, które wskazują na konkretnego użytkownika.

Zwróćmy więc uwagę na słowa, na tytuły rozdziałów jego książek lub samych książek. Ach, jakież piękne i dosadne są niektóre z nich:

- Odyseusz czy playboy? Kulturowa odyseja człowieka oto do czego prowokuje Odyseja przeczytana dzisiaj;

- Wartości w eterze, Okruchy wartości - bardzo się cieszę, że o warstościach rozmawiać można pragmatycznie, a nie wyłącznie na klęczkach;

- Pan Cogito czy Mister Tarzan - to świetne połączenie kultury wysokiej i popkultury, tak trzymać!;

- Bruderszaft z Kainem. Medytacje nad moralnym spadkiem po $P R L$ - bynajmniej nie pytamy, czym przepijano z Kainem, mamy za to świetną metaforę opisu systemu wartości minionej epoki.

Ale potraktujmy takie stwierdzenia jako sympatyzujące spojrzenie nieprofesjonalisty. Nie zabierając chleba znawcom teologii i imponujących dokonań księdza arcybiskupa, mam zamiar skoncentrować się na kilku jego tekstach i nielicznych zagadnieniach czy stanowiskach z nich wynikających. Interesuje mnie pytanie o rolę refleksji medioznawczej arcybiskupa Życińskiego w kontekście wewnętrznym (całego dorobku arcybiskupa), a także zewnętrznym (gdy mowa o mediach ogólnie). To, że poruszał problematykę mediów w swoich pismach, to rzecz powszechnie znana. Pytam więc, czy można przypisać mu jakiś w miarę trwały zespół przekonań na temat 
audiowizualności: percepcji, analizy i wpływu mediów na nasze życie.

Myślę przede wszystkim o nastepujących tekstach: o Przerwanej rozmowie $\mathrm{z}$ arcybiskupem dziennikarki Aleksandry Klich, zatytułowanej Świat musi mieć sens z 2012 roku$^{1}$. A także o kazaniu Kultura godności czy dyktatura sukcesu oraz wykładzie Horyzont wartości jako przestrzeń dialogu Kościoła z kultura wspótczesną.

Co Józef Życiński proponuje na tym obszarze?

- Zasadę dialogu jako niewzruszoną. Zadaje jednak pytanie, czy warto rozmawiać z każdym - w tym przypadku odzywają się watpliwości, gdyż odpowiedź na nie „zależy od poziomu dziennikarstwa";

- Odejście od stereotypów jako spłaszczonych i okrojonych wersji oceny złożoności człowieka. Jednocześnie, powiada Arcybiskup - musi istnieć świadomość niebezpieczeństwa powstania nowych stereotypów (czyli „oczywistych oczywistości");

- Etyczny wymiar polskich zmian kulturowych i społecznych. To bardzo ważne stwierdzenie. Żyjemy w czasach zagrożenia etyki, ale jednocześnie nie mamy języka do jej opisu i repertuaru sankcji dla łamiących jej przykazania. Podkreślam nader często wystepujące określenie „etyka” zbliżające Życińskiego autora do tych wszystkich, których uwiera instytucjonalny podział na religię i etykę - albo

1 Świat musi mieć sens. Przerwana rozmowa arcybiskupa Józefa Życińskiego i Aleksandry Klich, Warszawa 2012 (wersja e-book). 
wydaje się wątpliwy. Zwykle duchowni piszą o „religii”, uznając, że mieści się tam również refleksja etyczna. Ale rodzi się po lekturze jego pism sugestia, że mówimy o bardzo zbliżonych do siebie kategoriach - wskutek tego być może katolik nie ma co kruszyć kopii o etykę?

Jeśli popatrzeć na zestaw tematów Przerwanej rozmo$w y$, to nie dziwi mój zamiar traktowania pisarstwa (także kazań) abp. Życińskiego jako elementów repertuaru coodzienności:

- Po co nam Bóg? Wątpienie jest błogosławione - no cóż, kilkaset lat wcześniej inkwizycja zacierałaby ręce, gotowy to dla niej materiał;

- Cierpienie - to niewątpliwie zakres ogólnoludzki, chociaż też należy do sfery kościelnej;

- Wolność - zarówno poważny problem religii, jak i ważne zagadnienie dnia codziennego;

- Otwartość, samotność, przyjaźń, prawda - o tym dyskutujemy (a na pewno powinniśmy prowadzić rozmowy) jak najczęściej;

- A tu zaskoczenie: kobieta, seks - bardzo ważny problem pod piórem księdza, ten ksiądz musi być odważny i... mądry;

- Pieniądze, Internet, to nasza codzienność - dobrze byłoby mieć pod ręką księdza, z którym można porozmawiać o takich sprawach.

Zadajmy pytania i spróbujmy na nie odpowiedzieć mianowicie: co robić dzisiaj z myślą Józefa Życińskiego, medioznawcy i filozofa, poświęconą mediom? Zapakować 
i czekać na kolejne rocznice, czy odkurzać w odpowiednim momencie, żeby błyszczała, przyciągała? Czy jest ona żywa, czy chce się ją traktować jako punkt wyjścia do kolejnych przemyśleń, czasem odległych sporo od wzorca? A gdy odpowiedź będzie pozytywna na ostatnie z nich, to nadal drążmy: czy owa myśl ma w sobie coś naturalnie prowokującego, czy jest otwarta na nowe doznania pod wpływem nowych faktów?

Zacznijmy od tego, że Józef Życiński autor nakreślił dwa obszary antynomiczne (z nadania autora - bo takie być nie muszą) względem siebie: telewizja i Internet.

\section{A.Telewizja, czyli „Wielki Brat”}

Telewizja dla księdza katolickiego powinna przede wszystkim być szansą - na ewangelizację na przykład. A jednak nie ma jej na tym horyzoncie refleksji. Znajdziemy wzmiankę, że obecnie Arcybiskup nie ogląda jej zdecydowanie, a w młodości uważał nawet sensację w TVP za nudną. Znajdziemy też potępienie Big Brothera, jako sztandarowego przykładu „kultury bezwstydu”. Jednocześnie Życiński potwierdza, że media dzisiaj stanowią poważne wyzwanie i są najzwyczajniej ważne dla człowieka - i dla bardzo dużych części grup ludzkich. Jedną z przyczyn jest zapewne ich mentalny stan: „Społeczeństwo bez wielkich ideałów, w którym ludzie żują gumę i wymieniają się ploteczkami, może istnieć, ale ja się boję takiego świata. Świat musi mieć sens". 
Rodzi się pytanie, czy sensem świata ludzi mogłyby być ploteczki i żucie gumy. Aleksandra Klich świetnie ripostuje w wielu miejscach (niedokończonej - przepraszam: przerwanej) rozmowy. I zawsze otrzymuje odpowiedź Życińskiego: „ale dokonałem wyboru, w takim świecie nie mógłbym żyć”. No cóż, niezbyt oryginalne to stanowisko - niedaleko mu do pocztu krytyków kultury masowej, widzących w niej wyłącznie mechanizmy odmóżdżania i ogłupiania. Pozostaje wzruszenie ramion: tak być nie musi. W każdym razie tak nie będzie w bardzo niedalekiej przyszłości, bo ich używanie (partycypacja w tym procesie!) ma więcej wspólnego z kreacją niż biernym odtwarzaniem. Już dłużej nie możemy konsumować obrazów tradycyjnie i bezsensownie: bo trzeba je wybrać spośród setek kanałów i stron WWW. Więc istotnie ten proces polega na szukaniu znaczeń - różnica wobec starej semiotyki polega na tym, że nie ma już dłużej pani nauczycielki, która zna prawidłową odpowiedź na pytania. Zagubiony i pozbawiony tożsamości prosument (po części konsument, po części producent) szuka sensu bez mapy i narzędzi. Świat musi coś znaczyć, istotnie. Może wystarczy czynność poszukiwania Graala, a może sama relacja z jego poszukiwań?

Inną kwestią zmuszającą do nakreślenia negatywnej opinii o TV jest „zanik kultury wstydu”, brutalne wejście w intymność przez przekazy i media, ale przede wszystkim konflikt godności z sukcesem. Dzisiaj widzi się w innym człowieku rywala, a sukces staje się najważniejszą wartością. Dodałbym, że istotnie „Wieki Brat” opowiada o tym, w jaki 
sposób (elegancko, zgodnie z regułaminem) wejść w spór, zrobić coś szybko, sprawnie i kreatywnie - czyli na przykład obalić jakąś cząstkę stereotypów. Warto więc, po tylu zapewnieniach o antystereotypowym nastawieniu, przyjrzeć się dokładniej pierwszemu głośnemu reality show w Polsce.

Mówimy o kulturze bezwstydu czy raczej braku komunikacji między pokoleniami? W audycji z 2001 roku (TVN) poznajemy grupę osób, której zachowania nauczyciele niekoniecznie chcieliby stawiać za wzór do naśladowania. Nie są to jednak ludzie zachowujący się w sposób godny napiętnowania. To polska „średnia” (a bez wątpienia sytuują się powyżej średniej, jeżeli chodzi o wykształcenie i motywacje). Tym samym nie widać powodu, żeby w sposób szczególnie negatywny ocenić ich język, zachowanie i deklarowany system wartości.

Taką też perspektywę opisu i oceny tego zjawiska najrozsądniej przyjąć: „Wielki Brat” zawiera to wszystko, co już było znane telewidzowi wcześniej. Jego „zasługą” zaś jest upowszechnienie i tym samym upublicznienie tego, o czym wszyscy wiedzieli, a niewielu mówiło.

Przypomnijmy²: zaczęło się ostro i bezkompromisowo. Rada Etyki Mediów wyraziła 6 marca 2001 roku zaniepokojenie w związku z rozpoczęciem w Polsce emisji programów telewizyjnych typu Big Brother. Uznano, że po pierwsze - nazwa nawiązuje do orwellowskiej wizji

2 Zob. W. Godzic, Telewizja i jej gatunki po „Wielkim Bracie”, Kraków 2004. 
totalitaryzmu. A dalej, oczywiście, sam język prowadził autorów oświadczenia: „Przypomnijmy więc czas, kiedy w Polskiej Rzeczypospolitej Ludowej aparat partii komunistycznej PZPR śledził życie poddanych swojej władzy obywateli za pomocą donosicielstwa, rewizji w domu i na ulicy, podsłuchu i kontroli korespondencji, tak że nikt i nic nie było w ochronnej sferze prywatności". Jakkolwiek absurdalnie by nie brzmiało oskarżanie Holendrów o szerzenie totalitaryzmu rodem ze Wschodu, to strategia wydaje się oczywista: polega ona na zdecydowanie negatywnej ocenie takich programów, i to na wszystkich płaszczyznach.

Istotnie, trudno w tej sprawie zachować obiektywizm. Na przykład rozpowszechniona opinia ojca duchowego projektu, Edwarda Miszczaka, o kulturotwórczej roli tej audycji, wydawała się co najmniej przesadzona, a dla bardzo wielu była porównaniem niestosownym. W wywiadzie z Michałem Gabrysiem i Mirosławem Grassą (w pracy Podglądanie Wielkiego Brata3) twórca programu na pytanie prowadzących: „«Wielki Brat» to z pewnością głośny i kontrowersyjny projekt, ale czy ma według pana jakąś wartość kulturową, społeczną?", odpowiedział:

„Przyrównuję polską edycję do popularnej wersji teatru Kantora. I choć może nie był to teatr, a bardziej wesołe miasteczko, to na pewno była to opowieść o dzisiejszych Polakach, oczywiście z udziałem aktorów prowincjonalnych, amatorów. Jedyna różnica polega na tym, że w tym

3 Zob. Podglądanie Wielkiego Brata, red. W. Godzic, Kraków 2001. 
«teatrze telewizyjnym» nie ma reżysera i nie wiadomo, jak się skończy spektakl. Sam dawno nie widziałem ludzi bawiących się tak naturalnie, tak swobodnie improwizujących, w sytuacjach, które tylko na początku miały określony scenariusz"4.

Po upływie pewnego czasu i ostudzeniu emocji wydaje mi się, że Edward Miszczak miał dużo racji, sugerując swoim porównaniem (jak można się jedynie domyślać, gdyż nie było ono rozwijane) istotną wagę tego programu dla kultury polskiej. Być może chodzi o to, że - tak jak u Kantora - aktorzy (o różnym stopniu profesjonalizmu) odgrywają scenki (o różnym stopniu scenariuszowego opracowania). To podobieństwo strukturalne. Ale bardziej intrygująca i kontrowersyjna w tym porównaniu wydaje się supozycja istnienia podobieństwa ideowego: oto banalny i dwuznaczny moralnie program telewizyjny potrafi odkryć takie prawdy o współczesnych Polakach, jakie w innych rodzajach sztuk i komunikatach albo nie są widoczne, albo kłamliwie przedstawione. To, że jednocześnie program sam wykrzywia i wykoślawia obraz, to już inne zagadnienie, i kto wie, czy nie jest to niezbywalny warunek istnienia jakiegokolwiek społecznego obrazu medialnego.

Jednak głosy, które dominowały i nadawały ton dyskusjom, nie pozostawiały jakiejkolwiek szansy na zobaczenie czegokolwiek wartościowego w tym programie. Oskarżano więc „Wielkiego Brata” o:

4 Tamże. 
- patologię, upadek norm i obyczajów („Takie programy są objawem patologii, patologii pracowników telewizji i tej części społeczeństwa, która to ogląda. Tym ludziom rozregulowały się normy i obyczaje. «Big Brother» wskazuje na wiele problemów. Odsłania ciężką chorobę społeczeństwa, a przynajmniej jego części. Nie bardzo wiemy, co zrobić z wolnością", jak wypowiadał się ksiądz Wiesław A. Niewęgłowski);

- propagowanie libertyńskich i skrajnie liberalnych zachowań - przy takich ocenach istotny był wątek ideologiczny („Wielki Brat” to nowy „rodzaj komuny”);

- utratę godności i propagowanie złych gustów („To ingerencja w prywatność, intymność, które są szczególnie cenną wartością w czasach, gdy jesteśmy najbardziej narażeni na jej utratę. Rezygnacja na własne życzenie z tego, co nazywamy wstydem, intymnością, to najgorsze w tym wszystkim. Nie ma na to usprawiedliwienia. Nawet jeśli się weźmie pod uwagę względy materialne czy chęć zaistnienia, zrobienia iluzorycznej kariery w mediach. Motywy, uważam, są niskie i niepokojące”, jak twierdziła Magdalena Bajer, przewodnicząca Rady Etyki Mediów).

Warto zwrócić ponadto uwagę na charakter tych wypowiedzi: są one na ogół bezwarunkowe, formułowane jako prawdy jedyne, poza jakąkolwiek możliwością negocjacji (bo w etyce nie ma pola negocjacji). Wydaje się więc słuszna opinia Tomasza Gobana-Klasa o podstawowej cesze pierwszych wypowiedzi intelektualistów: „Zaprzeczeniem orwellowskiego systemu Big Brother, czyli społeczeństwa 
zamkniętego, jest popperowskie społeczeństwo otwarte, wolne i swobodnie się komunikujące. Jak wskazywał Popper, nie jest to w smak wielu filozofom i autorytetom moralnym. Profesor Jacek Kurczewski wysunął nawet tezę, że wolny człowiek nie ma prawa uczestniczyć w takich programach, pozbawiają go bowiem jego prywatności, a to należy do praw niezbywalnych. Paradoksalnie wrogami tego telewizyjnego show okazały się zatem instytucje i osoby, które zdawałoby się powinny cenić otwarte społeczeństwo i strzec wolności mediów jak źrenicy oka («Big Brothera»)”.

Bez wątpienia „Wielki Brat” „przeorał polską scenę publiczną". Z jednej strony upowszechniły się i były na ustach wszystkich neologizmy i na ogół niepoprawne gramatyczne frazy, takie jak „nominacje” (w sensie negatywnego naznaczenia), „coś tam, coś tam” na oznaczenie sytuacji, w której na ogół użytkownik nie ma wystarczającej sprawności językowej do prowadzenia dalszej rozmowy. Ponadto w wielu miejscach publicznych zapanował szał tak zwanych nominacji: $w$ wielu przedszkolach dzieci bawiły się w Wielkiego Brata przy aprobacie opiekunek. Polegało to na tym, że ustawiły w sali drewniany domek i zarządzały nominacje, w wyniku których nielubiane dzieci musiały odejść. W innym miejscu bezrobotni urządzili sobie klatkę w remizie strażackiej na wzór blaszaka w Sękocinie, a kilku urzędników nazywało swoje gabinety (i opatrzyło stosownymi napisami) „pokojami zwierzeń”.

Arcybiskup Życiński pisze: „W końcu podglądaczami takich programów jak «Big Brother» są nie tylko młodzi 
ludzie, ale też emeryci. Oni również patrzą przez dziurkę i przełykają ślinę”. „Chodzi o godność człowieka [...]. Więcej godności mają Afrykanie protestujący niż Europejczycy, dla których godność jest pojęciem abstrakcyjnym - nie można handlować prywatnością"6.

Z Afrykanami przebijającymi nas godnością jest inaczej: nie przegonili, bo nie o to chodzi. Oto wiadomość $\mathrm{z}$ „Newsweeka” informująca o powstaniu pierwszych sieci telewizyjnych obejmujących swoim zasięgiem cały kontynent. Twierdzi się, że ważną częścią procesu jednoczenia afrykańskich kultur stał się „Big Brother Africa”. Zawładnął wyobraźnią mieszkańców tego kontynentu, jego trzecia edycja spowodowała powstanie klubów fanów: uczestnicy objeżdżają całą Afrykę, towarzyszą im tłumy telewidzów. $\mathrm{Na}$ kontynencie, na którym tylko 4 proc. z 900 milionów mieszkańców posiada telewizor, „Wielki Brat” z RPA robi furorę. Czego zaś uczy? Producent Carl Fisher twierdzi, że: „Program uwydatnia narodowe stereotypy: mieszkaniec RPA jest arogancki, a Kenijczyk apatyczny. Ale w końcu okazuje się, że mieszkańcy domu «Wielkiego Brata» są tacy jak my, są po prostu Afrykanami”.

Nawet jeśli uznamy znaczną część tej wypowiedzi za promocję programu, to $\mathrm{w}$ świetle tego, co już wiemy

\footnotetext{
5 Świat musi mieć sens. Przerwana rozmowa arcybiskupa Józefa Życińskiego i Aleksandry Klich, dz. cyt., s. 95.

6 Tamże, s. 106.

7 K. McGregor, Wielki Brat połączy wszystkich Afrykanów, „Newsweek Polska", 31.08.2003.
} 
o recepcji „Wielkiego Brata” w Turcji i Australii, wydaje się oczywiste, że programy tego typu spełniają ważną społeczną rolę - pozwalają poznać i zrozumieć motywacje działań ludzi z odmiennych kultur i ras, wyznających odmienne religie. Filozof i biskup katolicki ma rację, tak formułując zagrożenia, natomiast Józef Życiński, medioznawca i kulturoznawca, musiałby w swojej analizie być bardziej powściągliwy.

Z tą audycją wiąże się ponadto problem bardziej ogólny znaczenia audycji telewizyjnych. Dla kogo przeznaczone są audycje, kto je zamówił, czego oczekuje? - to problemy, na które niełatwo odpowiedzieć. Ich sens zależy od stacji, pasma, godziny, sąsiedztwa w strumieniu, zapowiedzi... ogólnie ramówki.

Przypomnijmy, że to kino ponad 100 lat temu było postrzegane jako czynność spoglądania przez dziurkę od klucza, a widz jako bezpieczny voyeur. Teraz możemy powiedzieć, że reality show był oglądany przez wszystkie grupy telewidzów (z przewagą dojrzałych kobiet z małych miasteczek), bo ciekawi ich życie innych, ale nie mają odwagi poprosić sąsiadkę o szklankę cukru jako wstęp do rozmowy. Tym razem miałoby za nich zrobić to medium.

I dalej ocenia arcybiskup: „Więcej godności mają Afrykanie protestujący niż Europejczycy, dla których godność jest pojęciem abstrakcyjnym - nie można handlować prywatnością"8. Już pokazywałem, że tak być nie musi

8 Tamże. 
w Afryce - chętnie wspomnę o Turcji i kilku krajach Europy. W tych ostatnich „Wielki Brat” odwzorowywał układ społeczny i pozwalał odczytywać napięcia w wielu grupach.

I znów cytuję Życińskiego: „Chyba że chcemy, żeby nasz świat zamienił się w magiel”. Audycja Magiel towarzyski przychodzi na myśl - magiel już istnieje. Rozumiem uprawianie antycelebrytyzmu, ale taka działalność nie może być zbyt radykalna, gdyż odklei się wówczas od rzeczywistości. Trudno zgodzić się na łatwy stereotyp, że wyłącznie „najgorszy sort społeczeństwa” ogląda tego typu programy. Trudno, bo jest to kultura dla milionów odbiorców, kształtuje ich gusty. Oni zaś „wyciągają” sensy, o jakich nam się nie śniło. To kultura wzorcotwórcza, urocza i łatwa - w żadnym przypadku nie jest „totalnie zła”. I tu: „Houston mamy problem”, bo prawdopodobnie ta sytuacja wymaga dialogu - tak nas uczył autor Życiński, a nie odwracania się plecami przez arystokratów ducha. Moja namowa do włączenia zjawiska celebrytyzmu i głupawych audycji TV do głównego nurtu refleksji humanistycznej podąża za głęboką myślą arcybiskupa, chociaż wydaje się przeciwna jej na pierwszy rzut oka. Jestem bliski myśli autora Okruchów wartości, że trzeba umiejętnie postawić granice między tym, czym warto, a czym nie warto się zajmować. Agresywnej głupoty i kiczu umysłowego, „eutanazji rozumu" (określenie Życińskiego) nie akceptuję jako postawy w wielu przypadkach. Podobnie jak autentycznych, nastawionych na zysk działań rodziców, którzy wystawili siebie i swoje dzieci na pokaz w Internecie. 
Gdy pada stwierdzenie: cóż to za szczęście dla Polaków z nowego telewizora? Odpowiadam pytaniem: $w$ imię czego odebrać im to „szczęście”? A może zaprowadzi ono do bardziej szlachetnych i finezyjnych jego form? Nie postępujmy jak konkwistadorzy, nie zabierajmy im (nam samym?) zabawek czy obiektów kultowych, tylko pokażmy alternatywne drogi i procesy - walczmy o/na wartości. Być blisko, oddziaływać poprzez strategię partyzantki semiotycznej - czyli konstrukcję znaczenia końcowego oto program.

Oto dająca do myślenia fraza z tekstu Umberta Eco, który usiłował przed laty wyjaśnić swojej ośmioletniej córeczce zawiłości prawdy i fałszu w telewizji. Powiedział, że ta maszyna semiotyczna posługuje się taką zasadą: „Ja wiem, że ty wierzysz, że rozumiesz to, co wydaje $\mathrm{Ci}$ się, że ja powiedziałem, ale nie jestem pewny, czy Ty zdajesz sobie sprawę z tego, że to, co usłyszałeś, nie jest tym, co ja miałem na myśli"’.

\section{B. Internet}

Józef Życiński o Internecie myśli coś przeciwnego niż o telewizji. Spytajmy: czy był tak młody duchem, jak dzisiejsze pokolenia dwudziesto-, trzydziestolatków, odwracajace się radykalne od TV, a czerpiące całą wiedzę z sieci?

9 U. Eco, Apocalypse postponed, Bloomington-Indianapolis 1994, s. 97. 
Twierdzi, że Internet poszerzył nasze uczestnictwo w świecie - tam właśnie znajduje przykłady solidarności i wrażliwości ${ }^{10}$. Wielu tak robi - ale w tym przypadku chodzi o coś głębszego. Józef Życiński prawdopodobnie polubił narzędzie, które pięć lat temu było czym innym niż obecnie. Jestem pewny, że dzisiaj, w zgodzie z postulatami App Generation ${ }^{11}$ - kulturą aplikacji - na mobilnych urządzeniach i rozszerzonej audiowizualności zaproponowałby zapewne kulturę odwrotną do tworzenia stereotypów, a przede wszystkim kulturę SLOW. Dorzućmy do tego dużą dawkę humoru i błyskotliwości Życińskiego.

Ta przepaść rzeczywiście jest trudna do zasypania wierzę, że jakości immanentnie tkwiące w Józefa Życińskiego modelu prowadzenia dialogu, zorientowaniu na godność człowieka i świat wartości znacznie mogą przybliżyć nas do poradzenia sobie z przeszkodami. Gdyby arcybiskup - „głos rozsądku polskiego Kościoła”, obdarzony „świetnym piórem” i „zmysłem polemisty” - chodził dzisiaj po tym świecie, zapewne zachowywałby się tak samo. Spotkalibyśmy go blisko szarego człowieka ulicy, normalsa, z którym - przekonany przeze mnie między innymi - oglądałby kolejne reality show nie dla zamulania umysłu, ale z ciekawości oponenta; stworzyłby z tego dyskurs. Zaś tego normalsa traktowałby bez protekcjonalnego i pobłażliwego

10 Świat musi mieć sens. Przerwana rozmowa arcybiskupa Józefa Życińskiego i Aleksandry Klich, dz. cyt., s. 104.

${ }_{11}$ Zob. H. Gardner, K. Davis, The App Generation, New Haven-London 2014 . 
poklepywania po plecach. Zapewne pomógłby swoim dowcipnym i jednocześnie ostrym spojrzeniem badaczom telewizji i Internetu. Tę pierwszą starałby się dowartościować, dając szansę na jej częściową rehabilitację - przyznając człowiekowi patrzącemu na ekran zdolność postrzegania bardziej subtelnego niż tylko emocje wyrażane przez rechot. Ten drugi, Internet, byłby przez naszego autora traktowany ze wzrastającym dystansem $z$ wielu powodów: na przykład z tej racji, że znikać zaczyna w nim pośrednik-często-artysta, a rządzi pieniądz i algorytm.

Tworzy się sytuacja, która daje wprawdzie możliwość komunikowania się podmiotów i grup w czasie rzeczywistym, co może być swoistym uwolnieniem, jak i obfitować w zasadzki oszustw tożsamości, stosowania mowy nienawiści. Internet sprzyjać zaczyna także postawom nadmiaru, w których nie da się wyartykułować niczego innego niż super, hiper, mega wow (albo odrzucenia) - tego zapewne obawiał się, kreśląc metaforę żujących gumę. A jego myślenie o godności drugiego człowieka jako najważniejszej przesłance współczesności mogłoby wielu rządzących kierować do konfesjonału. Na razie do konfesjonału. Co nam zaś, szaraczkom i normalsom, pozostaje do zrobienia według Józefa Życińskiego? Pożegnać się z frustracją, retoryką beznadziei i dbać o to, żeby nie dokonać eutanazji rozumu (jak rozumiem, własnego i innych - a to różne strategie). Następnie włączyć etykę do polityki, pozbywając się bożka skuteczności rozumianego jako uniwersalny miernik. A przede wszystkim - Arcybiskup poradziłby - iść na agorę 
i głosić dobro, miłosierdzie i moralne piękno, a także przekonanie o polisemii telewizji (i nie pomylić adresów - nie do Agory na Czerską, prędzej na Nowowiejską). Dla wielu, bardzo wielu taka interpretacja byłaby znakiem profetycznych zdolności autora Kultury godności czy dyktatury sukcesu. Czy myśl Józefa Życińskiego w tym zakresie po pięciu latach jest nadal aktualna? Bez wątpienia tak: już widzę arcybiskupa, który jednak daje się namówić na ogladanie audycji TV i jej jednoczesne semiotyczne dekonstruowanie. Musimy to robić $z$ jego pomocą, dla niego i dla nas. Nie czuję w sobie mocy kaznodziei (który w dodatku miałby pouczać prawdziwych księży i biskupów). Niemniej jednak namawiam ich do przyjęcia postawy partnerskiej, odległej od postawy tego-który-wie-najlepiej. Każdy z nas odnajduje małe sensy świata, które pomocne są do budowy większej konstrukcji, jaka czyni ze świata całość sensowną. Po drodze jednak posługujemy się stereotypami, bo po drodze nam z nimi: najzwyczajniej ułatawiaja poruszanie się po nieznanych ścieżkach. Problem w tym, czy i kiedy porzucimy stereotypy - bo porzucić musimy te znamiona myślenia ułatwiającego ponad miarę dochodzenie do istoty rzeczy.

Powyższe motto zawiera takie właśnie fakty, które funkcjonują jak prymitywne myślenie, jak stereotypy. Przecież w istocie „nieznany żołnierz” to najczęściej występujący napis na nagrobkach, więc najbardziej znany. Można łatwo wybrnąć $z$ tej pułapki semantycznej, jeśli mamy dostateczne kompetencje. $\mathrm{Z}$ kolei drugie motto to wyzanie celebryty, który zaszedł za daleko: gdy rozpoznał swoje 
beztalencie, to musiał brnąć dalej i dołączyć do licznego grona tych, którzy „znani są z tego, że są znani”. Nie zgadzam się z tym okrutnym wyrokiem, że nie mogę spytać księdza Józefa o jego stosunek do celebrytów.

Wśród wielu zalet abp Życiński miał tę potężną, na której zawsze zależy badaczom audiowizualności. Mianowicie nie lekceważył sensów, które inni - pozbawieni naszych kompetencji - mogli wyprowadzać z lektury dzieła artystycznego czy zwykłego i banalnego kontaktu z dziełem audiowizualnym. Mógł nie doceniać mediów (jak miało to miejsce w przypadku telewizji). Może częściowo dlatego, że telewizja wydawała mu się tak bardzo zdystansowana wobec kontaktu człowiek-człowiek. Telewizja jest przede wszystkim instytucją, zaś człowiek, który ja tworzy i nią zarządza, jest głęboko w niej, instytucji, schowany. Dlatego Józef Życiński stawiał na interaktywny (z konieczności) Internet. Postawił na bezpośredniość kontaktu, nie uwierzył instytucji. Ciągle jednak sądził, że człowiek rządzi w całym tym biznesie audiowizualnym. Że wszystko kręci się wokół niego, nawet wtedy, gdy te treści wydają się banalne czy najzwyczajniej głupkowate. 